\title{
CHILD SAFETY REFERENCE FRAMEWORKS: A POLICY TOOL FOR CHILD INJURY PREVENTION AT THE SUB-NATIONAL LEVEL
}

\author{
Beatrice Scholtes ${ }^{1,2}$, Peter Schröder-Bäck ${ }^{1,3}$, Morag Mackay ${ }^{4}$, Joanne Vincenten ${ }^{1}$, Helmut Brand ${ }^{1}$ \\ ${ }^{1}$ Department of International Health, Faculty of Health, Medicine and Life Sciences, CAPHRI School of Public Health and Primary Care, \\ Maastricht University, Maastricht, The Netherlands \\ 2Department of Public Health, University of Liege, Liege, Belgium \\ ${ }^{3}$ Faculty for Human and Health Sciences, University of Bremen, Bremen, Germany \\ ${ }^{4}$ Safe Kids Worldwide, Washington DC, USA
}

\begin{abstract}
SUMMARY
Objectives: The aim of this paper is to present the Child Safety Reference Frameworks (CSRF), a policy advice tool that places evidence-based child safety interventions, applicable at the sub-national level, into a framework resembling the Haddon Matrix.

Method: The CSRF is based on work done in previous EU funded projects, which we have adapted to the field of child safety. The CSRF were populated following a literature review.

Results: Four CSRF were developed for four domains of child safety: road, water and home safety, and intentional injury prevention.

Conclusion: The CSRF can be used as a reference, assessment and comparative tool by child safety practitioners and policy makers working at the sub-national level.
\end{abstract}

Key words: child safety, injury prevention, health inequalities, sub-national, inter-sectoral action

Address for correspondence: B. Scholtes, Department of International Health, Faculty of Health, Medicine and Life Sciences, CAPHRI School of Public Health and Primary Care, Maastricht University, p. o. box 616, 6200 MD Maastricht, The Netherlands. E-mail: beatrice.scholtes@maastrichtuniversity.nl

https://doi.org/10.21101/cejph.a4477

\section{INTRODUCTION}

Europe has some of the highest and lowest injury rates in the world with large differences in injury mortality between highincome countries and low and middle-income countries (1). In 2010, in the European Union intentional and unintentional injury deaths for $0-19$ year olds ranged from $5 / 100,000$ in the Netherlands to 24/100,000 in Lithuania (2). Despite large reductions in overall mortality between 2000 and 2010, inequalities between countries are increasing (3). Additionally, there are large inequalities within countries, and the substantial improvements in injury mortality rates in recent years have not been spread equally across society (4-6).

Child injury is a complex, 'wicked' problem $(7,8)$, and its prevention requires the participation of multiple stakeholders. Actors working across the whole society (public sector, private sector and civil society) and at all levels of government, from the local to international level, have a role to play (9).

In this paper we focus on the sub-national level of governance for child injury prevention for several reasons. First, much attention has been paid to the role of the European and national levels of governance in injury prevention, with encouraging results (10). However, while policies are often developed at the national level, implementation and enforcement, much of the action, take place at the sub-national or local level - an area of research somewhat understudied.

Second, the capacity of the sub-national level to focus upon the specific needs of its population is an important characteristic. Diverse risk factors for child injury such as socioeconomic position, employment status, parental education, area deprivation, and types of settlement cluster in pockets of society and require tailored action (11-14). Thus, effective action at the sub-national level is required to address regional inequalities in child injury rates.

Third, the role of the sub-national level for public health is increasing in many countries due to decentralization $(15,16)$. But, efficient delivery of child injury interventions at the sub-national level may be hindered due to a lack of leadership, infrastructure and capacity $(15,17)$.

In this paper we describe the development of a policy advice tool, applicable at the sub-national level, named Child Safety Reference Frameworks (CSRF). The study was part of the European Commission funded project, Tools to Address Childhood Trauma and Children's Safety (TACTICS). The CSRF list evidence-based interventions, applicable at the sub-national level, covering four domains of child safety: road, home and water safety, and intentional injury prevention. 


\section{MATERIALS AND METHODS}

\section{Haddon Categories and Design of CSRF}

The design and use of the CSRF is built upon the Haddon Matrix (18) and was first used in a regional health management project in Spain (19). It was further refined in the European commission funded project "Benchmarking Regional Health Management II" (BEN II) (20). Using the experiences of Peiro et al. and Brand et al. $(19,20)$ we refined the methodology and applied it to child safety at the sub-national level.

We developed a CSRF for each of four domains of child safety: water safety, road safety, home safety, and prevention of intentional injury. To identify suitable interventions to populate the four CSRF, each domain was clearly defined for scope. The following definitions were used:

- Road safety: prevention of car/bus, pedestrian, bicycle, moped/ motor scooter, all terrain vehicle (ATV), and farm vehicle injuries;

- Home safety: prevention of falls (within the home and related to public/school playground equipment), burns/scalds, poisoning, choking/strangulation, drowning in the home (e.g. in a bathtub);

- Water safety: prevention of drowning in pools (public and private) or open water and beach safety;

- Intentional injury: prevention of abuse/neglect, violence, suicide, and self-harm.

We used the definition of good practice as outlined in the European Child Safety Alliance (ECSA) Child Safety Good Practice Guide (21) to guide the selection of appropriate evidence-based interventions.

- "An intervention that has been evaluated and found to be effective (either through a systematic review or at least one rigorous evaluation); or

- An intervention where rigorous evaluation is difficult but expert opinion supports the practice and data suggest it is an effective policy/intervention (e.g. use of personal floatation devices to prevent drowning); or

- An intervention where rigorous evaluation is difficult but expert opinion supports the practice and there is a clear link between the policy/intervention and reduced injuries (e.g. secure storage of poisoning); and

- The intervention has been implemented in a real world setting so that the practicality of the intervention has also been examined."

The CSRF is applicable to the sub-national level of governance. Within Europe there are diverse jurisdictional differences regarding the distribution of political power between national, sub-national and local levels. Therefore, we developed the following inclusion criteria in attempt to accommodate these differences without being too broad.

We defined a sub-national level intervention for the purposes of the CSRF as:

"An intervention that is implementable, enforceable or possible to monitor on the sub-national (land, province, department) or local level (city, municipality, commune). This includes interventions where the decision to implement is made at the national level but responsibility for method of implementation or enforcement lies at the sub-national or local levels."
This definition excludes manufacturing standards such as car safety devices (e.g. airbags), as these are generally developed, implemented and enforced by national or European bodies. Legally banned items such as dangerous toys were excluded for the same reason. Legislative interventions such as laws mandating bicycle helmets were included in the CSRF where either passing laws at a sub-national level was possible or enforcement is carried out at the sub-national level. Clinical recommendations for the treatment of injuries were excluded, except where implementation could lead to prevention (e.g. guidelines regarding diagnosis of physical abuse that can protect the child from further abuse).

To be included in the CSRF interventions needed to conform to both the definition of evidence based good practice and be applicable at the sub-national level.

\section{Literature Review}

A literature search for review articles was conducted in February 2012 using the PubMed and Cochrane Database. Search terms used included 'injury' and 'prevention', as both mesh terms and free text. The search was limited to children ( $0-18$ years) and to review articles published in the last 10 years in English, French and German.

The search yielded 733 results, after excluding irrelevant articles 227 remained, these were reviewed in greater detail for interventions meeting the criteria described above. Reference lists of included articles were also searched for additional publications not picked up in the initial search, but these did not yield any other interventions. Finally, interventions outlined in the following 'core' documents were also included: the European Child Safety Alliance (ECSA) Child Safety Good Practice Guide (21) (including the 2010 Addendum) (22), ECSA Child Safety Report Card 2012: Europe Summary (23), ECSA National Action to Address Child Intentional Injury - 2014 (24), WHO European and World reports on unintentional child injury $(25,26)$, and the WHO world report on violence and health (27).

\section{Populating Four CSRF Tables}

Interventions were assigned to the appropriate row in the CSRF tables using Haddon's definitions of time phase (pre-event, event and-post event):

- Pre-event: interventions designed to prevent the injury event from occurring (e.g. separation of pedestrian walkways from roads);

- Event: interventions designed to protect host (minimise energy exchange) in the event of an injury (e.g., bicycle helmets, surfacing materials under public playground equipment);

- Post-event: interventions designed to reduce the impact and maximise salvage (e.g., poison control centres, child helplines) (18).

When assigning the interventions to the appropriate column we modified the definitions of host, agent and environment slightly by assigning them based on who or what the intervention targeted or whose behaviour it attempted to change. The headings of the columns were defined as follows:

- Host: interventions targeting the person at risk of injury. In the case of home injury, parents/caregivers were included in this 
column to account for the importance of high quality care and supervision to prevent injuries;

- Agent: interventions targeting the agent/means of/vehicle transferring the energy (e.g., car, gun, assailant, water);

- Physical environment: interventions targeting the physical characteristics surrounding the event (e.g., road, building, playground);

- Social environment: interventions targeting the social environment surrounding the event including all laws/legislation (e.g. laws regarding vehicle speed) as well as the existence of committees, practice guidelines, surveillance, etc.

The CSRF were reviewed and validated by the Scientific Committee of TACTICS and selected experts. The four finalised CSRF addressing evidenced-based interventions at the sub-national level are presented in Tables 1, 2, 3 and 4.

\section{RESULTS}

Overall, 127 interventions were identified: 27 in road safety, 26 in home safety, 23 in water safety, and 51 in intentional injury prevention. $71 \%$ of interventions fell into the pre-event phase, $11 \%$ into the event phase and $18 \%$ into the post-event phase. There were no interventions identified in any domain for two cells: event/policies targeting the agent and post-event/policies targeting the physical environment. The distribution of interventions over the time-phases varies by injury domain. In road and water safety most of the interventions fell into the pre-event phase (17 and 18, respectively) followed by the event phase ( 9 and 1) and finally the post-event phase (1 each). In home safety and intentional injury prevention most of the interventions were also in the pre-event phase (23 and 32, respectively). In the event phase, there was one intervention in home safety and none in intentional injury prevention. In the post-event phase, there were 2 in home injury and 19 in intentional injury prevention.

\section{Application of Frameworks}

In order to apply the CSRF to a sub-national region, a questionnaire was developed and validated in collaboration with partners of the TACTICS project from 6 countries. To get a more nuanced overview of activities in the area of child injury prevention at the sub-national level the questionnaire asks two things: whether the intervention is in place in the territory in question, and the estimated percentage of the target population covered by the intervention. For assessment purposes the intervention had to be implemented in the territory in question and covering at least $75 \%$ of the target population to be considered implemented.

\section{Rapid Appraisal}

After inputting the quantitative data from the questionnaire the user can conduct a rapid appraisal of child injury prevention activities in the territory in question. For each cell of the CSRF the number of interventions implemented (and reaching more than $75 \%$ of the target population) is counted and then calculated as a percentage of the total number of interventions for that cell. Using the software Microsoft Excel, conditional formatting is applied to the percentages assigning a shade of grey, with white (no colour) representing $0 \%$ of interventions implemented and dark grey representing $100 \%$ of interventions implemented (Table 5).

\section{DISCUSSION}

The CSRF were developed for practitioners and policy makers working in child injury prevention at the sub-national level as a reference, assessment and comparative tool. As a reference tool the CSRF can help bridge the gap between research and practice by providing accessible information on sub-national level evidencebased interventions. In a second step the CSRF and questionnaire can be used to assess which interventions are already in place in the territory and to what extent they cover the target population. The results can then be used to perform a rapid appraisal providing a visual representation of the state of affairs - showing where interventions are in place and where there are gaps (Table 5). Finally the CSRF can be used to compare the situation within a territory in terms of intervention coverage, over time and from territory to territory (nationally and internationally).

The applicability of the CSRF to the sub-national level is important due to the influence of this level of governance on injury prevention, such as in environment modification $(25,26)$. In a situation where political power may not be matched by a deep understanding of child safety issues, the CSRF as a reference tool could complement the policy maker or practitioner's knowledge of local geography and populations with information on evidence based solutions. However, the interventions included in the CSRF are not weighted by effectiveness, making it difficult, based on the CSRF alone, to choose among them. Similarly, some interventions were only found to be effective when implemented in parallel with others, e.g. a multi-faceted approach such as media campaign and speed limit enforcement. Though, as a rule, a combination of approaches is usually found to be most effective and is therefore recommended (21).

The component of the questionnaire regarding the level of implementation (percentage of target population coverage) of the intervention is an improvement of the previous Reference Framework methodology (28). It draws attention to the importance of equitable intervention coverage (proportionate universalism) (29) to address health inequalities and highlights interventions with low population coverage. The time required to complete the questionnaire, especially finding population coverage data, is a challenging aspect of the application of the CSRF. Though one could argue that if it is difficult or impossible to verify an intervention's existence and the extent to which it is implemented there is a clear gap in monitoring and evaluation - a valuable finding itself.

The questionnaire requires input from stakeholders in diverse sectors, which could also slow down the data collection process. Nevertheless, inter-sectoral action is a vital component of child injury prevention, thus, completing the questionnaire could be a good opportunity for practitioners and policy makers to build or improve their professional network. Equally, notwithstanding the length of time required to complete the questionnaire, once the data are placed into the CSRF the visual accessibility of the rapid appraisal reduces the time required to transmit the results to other stakeholders, leaving more time to discuss how to move forward. Additionally, users are not required to complete CSRF 
Table 1. CSRF - Road safety

\begin{tabular}{|c|c|c|c|c|}
\hline & 1 & 2 & 3 & 4 \\
\hline Road safety & $\begin{array}{l}\text { Policies and interventions } \\
\text { targeting the host (child) }\end{array}$ & $\begin{array}{c}\text { Policies and interventions } \\
\text { targeting the agent (vehi- } \\
\text { cle/driver) }\end{array}$ & $\begin{array}{l}\text { Policies targeting the } \\
\text { physical environment }\end{array}$ & Policies targeting the social environment \\
\hline Pre-event & $\begin{array}{l}\text { Pedestrian skills training to } \\
\text { improve child pedestrian } \\
\text { road crossing skills } \\
\text { Cycling skills training for } \\
\text { children } \\
\text { Media campaign at least } \\
\text { once in past five years tar- } \\
\text { geting child and adolescent } \\
\text { pedestrian, passenger and } \\
\text { cycling safety }\end{array}$ & $\begin{array}{l}\text { Regular alcohol sobriety } \\
\text { checkpoints } \\
\text { School-based programmes } \\
\text { for reduced drinking and } \\
\text { driving } \\
\text { Education regarding risks of } \\
\text { driver fatigue } \\
\text { Limit on engine size ( } 125 \mathrm{cc}) \\
\text { for learner moped riders }\end{array}$ & $\begin{array}{l}\text { Existence of traffic calming } \\
\text { measures (e. g. speed } \\
\text { bumps) } \\
\text { Separation of pedestrian } \\
\text { walkways from roads } \\
\text { Presence of cycling lanes or } \\
\text { pathways }\end{array}$ & $\begin{array}{l}\text { Enforcement of drink driving law } \\
\text { Enforcement of curfew laws to restrict teen- } \\
\text { age driving at night } \\
\text { Enforcement of legislation reducing vehicle } \\
\text { speeds in residential areas and school zones } \\
\text { Enforcement of law preventing children } \\
\text { younger than } 16 \text { from riding on all terrain } \\
\text { vehicles (ATV) } \\
\text { Regional ministry/government department } \\
\text { with mandated responsibility for child and } \\
\text { adolescent pedestrian, passenger/driver, } \\
\text { motorcycle and cycling safety } \\
\text { Government approved regional injury } \\
\text { prevention strategy with specific targets and } \\
\text { timelines related to child and adolescent } \\
\text { pedestrian, passenger/driver, motorcycle and } \\
\text { cycling safety } \\
\text { Policy that increases access to child passen- } \\
\text { ger restraint systems (CPRS) for disadvan- } \\
\text { taged families CPRS included as essential } \\
\text { child-care articles or taxed at lower rate or } \\
\text { subsidies offered through programmes target- } \\
\text { ing disadvantaged families }\end{array}$ \\
\hline Event & $\begin{array}{l}\text { Interventions combining } \\
\text { information dissemination } \\
\text { on child passenger restraint } \\
\text { safety with enhanced } \\
\text { enforcement campaigns } \\
\text { Interventions combining child } \\
\text { passenger restraint distribu- } \\
\text { tion, loaner programmes or } \\
\text { incentives with education } \\
\text { programmes } \\
\text { Regional/community or } \\
\text { school based education } \\
\text { approaches including free } \\
\text { provision of bicycle helmets }\end{array}$ & & & $\begin{array}{l}\text { Enforcement of seat-belt laws } \\
\text { Enforcement of law mandating child pas- } \\
\text { senger restraints } \\
\text { Enforcement of law requiring children to re- } \\
\text { main seated in rear facing car seats until } 4 \\
\text { years of age } \\
\text { Enforcement of law requiring children and } \\
\text { adolescents to remain seated in the back } \\
\text { seat of a motor vehicle until } 13 \text { years of age } \\
\text { Enforcement of law requiring children up to } \\
18 \text { years of age to wear bicycle helmets } \\
\text { Enforcement of legislation mandating hel- } \\
\text { mets for mopeds, motor scooters and ATVs }\end{array}$ \\
\hline Post-event & & & & $\begin{array}{l}\text { Surveillance systems including child road } \\
\text { injuries (based on emergency or police } \\
\text { data) that can direct prevention efforts to in- } \\
\text { jury types resulting in the greatest local bur- } \\
\text { den }\end{array}$ \\
\hline
\end{tabular}


Table 2. CSRF - Home safety

\begin{tabular}{|c|c|c|c|c|}
\hline & 1 & 2 & 3 & 4 \\
\hline Home safety & $\begin{array}{l}\text { Policies and interventions } \\
\text { targeting the child/child's } \\
\text { supervisor }\end{array}$ & $\begin{array}{l}\text { Policies and interventions } \\
\text { targeting the agent (chemi- } \\
\text { cals, cigarettes, water } \\
\text { temperature etc.) }\end{array}$ & $\begin{array}{l}\text { Policies and interventions } \\
\text { targeting the physical envi- } \\
\text { ronment (e.g., housing, } \\
\text { child care equipment) }\end{array}$ & $\begin{array}{l}\text { Policies and interventions } \\
\text { targeting the social } \\
\text { environment }\end{array}$ \\
\hline Pre-event & $\begin{array}{l}\text { Educational programmes } \\
\text { encouraging use of fall pre- } \\
\text { vention safety devices (e. g., } \\
\text { window safety mechanisms, } \\
\text { stair gates) } \\
\text { Fire safety skills training to } \\
\text { increase knowledge and } \\
\text { behaviour of both children } \\
\text { and parents } \\
\text { Home safety educational } \\
\text { interventions promoting the } \\
\text { installation of smoke alarms } \\
\text { and supplying alarm } \\
\text { Education/advocacy cam- } \\
\text { paigns around the safe use } \\
\text { of fireworks } \\
\text { Home safety education for } \\
\text { parents on the safe stor- } \\
\text { age of harmful chemicals } \\
\text { including provision of safety } \\
\text { materials } \\
\text { Individual-level education/ } \\
\text { counselling for parents on } \\
\text { unintentional childhood injury } \\
\text { prevention in the clinical } \\
\text { setting } \\
\text { Home safety counselling } \\
\text { programmes for parents (on } \\
\text { prevention of falls, poisoning, } \\
\text { burn etc.) } \\
\text { Hometing child and adolescent } \\
\text { such as home visiting pro- } \\
\text { grammes for new parents } \\
\text { Media campaign at least } \\
\text { once in past five years tar- } \\
\text { falliburn } \\
\text { andion }\end{array}$ & $\begin{array}{l}\text { Home safety interventions } \\
\text { for parents promoting a safe } \\
\text { hot water exit temperature }\end{array}$ & $\begin{array}{l}\text { Building codes requiring } \\
\text { working smoke detectors } \\
\text { in all public buildings (e.g., } \\
\text { hospitals, schools and } \\
\text { kindergartens) } \\
\text { Smoke detector give away } \\
\text { programmes targeting } \\
\text { high-risk neighbourhoods } \\
\text { and multi-faceted commu- } \\
\text { nity campaigns with specific } \\
\text { objective of installation of } \\
\text { smoke detectors } \\
\text { Non-voluntary building } \\
\text { codes for new dwellings } \\
\text { (legal standards to address } \\
\text { hazards related to falls, } \\
\text { fire injuries, other thermal } \\
\text { injuries, collisions, entrap- } \\
\text { ment, cutting and piercing, } \\
\text { drowning, electrocution and } \\
\text { poisoning) } \\
\text { Non-voluntary building } \\
\text { codes for existing dwellings } \\
\text { (legal standards to address } \\
\text { hazards related to falls, } \\
\text { fire injuries, other thermal } \\
\text { injuries, collisions, entrap- } \\
\text { ment, cutting and piercing, } \\
\text { drowning, electrocution, and } \\
\text { poisoning) } \\
\text { Policy that increases access } \\
\text { to childcare safety equip- } \\
\text { ment, such as stair gates, for } \\
\text { disadvantaged families (e.g. } \\
\text { regional equipment give- } \\
\text { away/loaner programmes) }\end{array}$ & $\begin{array}{l}\text { Enforcement of law requiring environmental } \\
\text { changes to windows in all buildings with } \\
\text { more than one storey (e.g. window guards } \\
\text { or locks) } \\
\text { Enforcement of law requiring safe design of } \\
\text { guardrails for all private and public buildings } \\
\text { to prevent falls from balconies and stairs } \\
\text { Enforcement of legislation requiring safe tap } \\
\text { water temperature } \\
\text { Enforcement of law controlling the sale of } \\
\text { fireworks } \\
\text { Enforcement of legislation requiring installa- } \\
\text { tion of smoke detectors in new and existing } \\
\text { houses } \\
\text { Government approved regional injury } \\
\text { prevention strategy with specific targets and } \\
\text { timelines related to child and adolescent fall, } \\
\text { poisoning, burn/scald and choking prevention } \\
\text { Incorporation of injury prevention and control } \\
\text { into the comprehensive nursing care of } \\
\text { children, families and communities } \\
\text { Regional ministry/government department } \\
\text { with mandated responsibility for child and } \\
\text { adolescent fall/scald/burn/choking prevention }\end{array}$ \\
\hline Event & & & & $\begin{array}{l}\text { Enforcement of standards requiring safe } \\
\text { depth of specified types of surfacing materi- } \\
\text { als under public playground equipment and } \\
\text { regular maintenance of those material }\end{array}$ \\
\hline Post-event & & & & $\begin{array}{l}\text { Poison control centres with education of pu- } \\
\text { blic regarding the use of centre } \\
\text { Surveillance systems including child home } \\
\text { injuries (based on emergency data) that } \\
\text { can direct prevention efforts to those injuri- } \\
\text { es resulting in the greatest local burden }\end{array}$ \\
\hline
\end{tabular}


Table 3. CSRF - Water safety

\begin{tabular}{|c|c|c|c|c|}
\hline & 1 & 2 & 3 & 4 \\
\hline $\begin{array}{l}\text { Water } \\
\text { safety }\end{array}$ & $\begin{array}{l}\text { Policies and interventions } \\
\text { targeting the child/child's } \\
\text { supervisor }\end{array}$ & $\begin{array}{l}\text { Policies and interventions } \\
\text { targeting swimming pool } \\
\text { design }\end{array}$ & $\begin{array}{l}\text { Policies and interventions } \\
\text { targeting the physical } \\
\text { environment including } \\
\text { presence of lifeguards }\end{array}$ & $\begin{array}{l}\text { Policies and interventions } \\
\text { targeting the social } \\
\text { environment }\end{array}$ \\
\hline Pre-event & $\begin{array}{l}\text { Water safety skills training for } \\
\text { children (including swimming } \\
\text { lessons after the age of } 5 \\
\text { years) to improve swimming } \\
\text { performance } \\
\text { Community-based education/ } \\
\text { advocacy to increase per- } \\
\text { sonal floating devices use } \\
\text { Parental education on impor- } \\
\text { tance of supervision } \\
\text { Programme of child home } \\
\text { visits that includes education } \\
\text { for parents on child water } \\
\text { safety } \\
\text { Media campaign at least } \\
\text { once in past five years target- } \\
\text { ing child and adolescent } \\
\text { water safety }\end{array}$ & $\begin{array}{l}\text { Enforcement of safety } \\
\text { standards for public swim- } \\
\text { ming pools, e.g., water } \\
\text { depth markings, step edges } \\
\text { marked with contrasting } \\
\text { colours, onsite safety equip- } \\
\text { ment, suction outlet covers } \\
\text { and chemical standards }\end{array}$ & $\begin{array}{l}\text { Existence of safe crossings } \\
\text { over open bodies of water } \\
\text { such as canals and irrigation } \\
\text { ditches } \\
\text { Well-marked swimming } \\
\text { areas free of hazards } \\
\text { Existence of water collection } \\
\text { container covers (e.g. wells) } \\
\text { with heavy grills } \\
\text { Policy requiring qualified risk } \\
\text { assessment of all designated } \\
\text { public water recreational } \\
\text { areas (e.g. assessment } \\
\text { conducted by qualified } \\
\text { inspector) } \\
\text { Investment programme } \\
\text { to renew infrastructure to } \\
\text { provide equitable access to } \\
\text { public swimming pools for } \\
\text { swimming lessons for school } \\
\text { age children } \\
\text { Signage around water } \\
\text { displayed using clear and } \\
\text { simple pictogram warning } \\
\text { signs }\end{array}$ & $\begin{array}{l}\text { Enforcement of law requiring mandatory use } \\
\text { of personal floatation device/lifejacket by } \\
\text { children while on the water (e.g., while boat- } \\
\text { ing, sailing, etc.) } \\
\text { Enforcement of legislation requiring isolation } \\
\text { fencing with secure, self-latching gates for all } \\
\text { pools, public, semi-public and private includ- } \\
\text { ing both newly constructed and existing pools } \\
\text { Policy governing water safety for leisure/rec- } \\
\text { reational programming at the community level } \\
\text { (e.g., minimum levels of supervision, training } \\
\text { or safety equipment, etc.) } \\
\text { Policy making water safety education, includ- } \\
\text { ing swimming lessons, a compulsory part of } \\
\text { the school curriculum } \\
\text { Ministry/government department with man- } \\
\text { dated responsibility for child and adolescent } \\
\text { water safety } \\
\text { Government approved regional injury } \\
\text { prevention strategy with specific targets and } \\
\text { timelines related to child and adolescent } \\
\text { water safety }\end{array}$ \\
\hline Event & $\begin{array}{l}\text { Training for parents and } \\
\text { caregivers in infant and child } \\
\text { CPR }\end{array}$ & & $\begin{array}{l}\text { Existence of adequately } \\
\text { qualified, trained and } \\
\text { equipped lifeguards }\end{array}$ & $\begin{array}{l}\text { Enforcement of law stating minimum number } \\
\text { of lifeguards required on beaches or other } \\
\text { areas designated for water leisure activities } \\
\text { Enforcement of law stating minimum num- } \\
\text { ber of lifeguards required at public pools }\end{array}$ \\
\hline Post-event & & & & $\begin{array}{l}\text { Surveillance systems (based on emergency } \\
\text { data/lifeguard incidence reporting) that can } \\
\text { direct prevention efforts to those injuries re- } \\
\text { sulting in the greatest local burden }\end{array}$ \\
\hline
\end{tabular}

for all four domains of child safety at one time, they can be done as separate assessments.

Inequalities in child injury rates, within and between countries, demonstrate the opportunity and necessity for good practice to cross borders to successfully reduce child injury rates. The CSRF provides a platform and context to compare and learn from other regions.

\section{CONCLUSION}

This policy tool, designed for child injury prevention practitioners and policy makers at the sub-national level, can be used as a reference, measurement and comparative tool. Addition- ally, the CSRF may provide opportunities for inter-sectoral networking, knowledge exchange and capacity building. We hope that this will encourage greater uptake of evidence based child safety interventions at the sub-national level, thereby improving child safety and reducing inequalities both within and between countries.

\section{Acknowledgements}

Parts of this paper have been published previously in the technical report of the TACTICS project, available at: http://www.childsafetyeurope.org/ tactics/child-safety-reference-frameworks.html.

Complete versions of the $4 \mathrm{CSRF}$, including citations and references, are available at http://www.childsafetyeurope.org/tactics/info/child-safetyreference-frameworks.pdf. 
The authors are grateful to Martina Abel, Veronika Benešov, Daniel Carlsson, Ulla Korpilahti, Jaana Markkul, Josep M Suelves, and Dóra Várnai for their input during the development of the questionnaire. We are also grateful to the scientific committee of the TACTICS project; Ronan Lyons, Michael Rigby, Lennart Köhler, Anders Hjern, Mika Gissler, and Denise Alexander for their participation in the development of the CSRF.

\section{Conflict of Interests}

None declared

\section{Funding}

Funding for this study was received from the European Commission under the EU Health Programme 2008-2013 project number 20101212

Table 4. CSRF - Intentional injury prevention

\begin{tabular}{|c|c|c|c|c|}
\hline \multirow[b]{2}{*}{$\begin{array}{l}\text { Intentional } \\
\text { injury }\end{array}$} & 1 & 2 & 3 & 4 \\
\hline & $\begin{array}{l}\text { Policies and interventions } \\
\text { targeting the child }\end{array}$ & $\begin{array}{l}\text { Policies and interventions } \\
\text { targeting the agent (including } \\
\text { perpetrators of violence and } \\
\text { weapons) }\end{array}$ & $\begin{array}{c}\text { Policies and interventions } \\
\text { targeting the physical } \\
\text { environment }\end{array}$ & $\begin{array}{l}\text { Policies and interventions } \\
\text { targeting the social } \\
\text { environment }\end{array}$ \\
\hline Pre-event & $\begin{array}{l}\text { Child sexual abuse prevention } \\
\text { programmes - teaching children } \\
\text { about body ownership, abusive } \\
\text { situations } \\
\text { School based programmes to } \\
\text { prevent violence (building upon } \\
\text { youth's social competencies and } \\
\text { skills) } \\
\text { School based suicide preven- } \\
\text { tion programmes (to improve } \\
\text { knowledge, attitudes and in some } \\
\text { cases help-seeking behaviour) } \\
\text { Media campaign increasing } \\
\text { awareness regarding maltreat- } \\
\text { ment and its prevention in last } \\
5 \text { years } \\
\text { Media campaign increasing } \\
\text { awareness regarding bullying and } \\
\text { its prevention in last } 5 \text { years } \\
\text { Media campaign increasing } \\
\text { awareness regarding suicide/self- } \\
\text { harm and prevention } \\
\text { Existence of programmes provid- } \\
\text { ing information about drug abuse } \\
\text { Existence of adult-supervised } \\
\text { after-school programmes for } \\
\text { school-age children } \\
\text { Extra-curricular activities such } \\
\text { as sports and recreation, art, } \\
\text { music, and drama for school age } \\
\text { children } \\
\text { Policy stating that life skills } \\
\text { education (including coping skills, } \\
\text { interpersonal communication, } \\
\text { goal setting, anger management, } \\
\text { and advocacy skills) a mandatory } \\
\text { part of school curriculum }\end{array}$ & $\begin{array}{l}\text { Early childhood development } \\
\text { programme } \\
\text { Parental education about abusive } \\
\text { head trauma (shaken baby } \\
\text { syndrome) } \\
\text { Existence of programmes to im- } \\
\text { prove parents' child rearing skills, } \\
\text { knowledge of child development } \\
\text { and encourage positive child } \\
\text { management strategies } \\
\text { Existence of support groups } \\
\text { to strengthen parents' social } \\
\text { network } \\
\text { Existence of services for adults } \\
\text { abused as children (mental } \\
\text { health referral) } \\
\text { Gang prevention programmes } \\
\text { Existence of home visitation } \\
\text { programme that focuses on } \\
\text { families at-risk of violence against } \\
\text { children } \\
\text { Existence of gun control policies } \\
\text { such as "gun buyback" and } \\
\text { weapon amnesties }\end{array}$ & $\begin{array}{l}\text { Incorporation of principles of } \\
\text { "Crime Prevention Through } \\
\text { Environmental Design" (CPTED) } \\
\text { in town planning } \\
\text { Existence of policies regarding } \\
\text { safe routes to schools } \\
\text { Availability of affordable childcare } \\
\text { facilities }\end{array}$ & 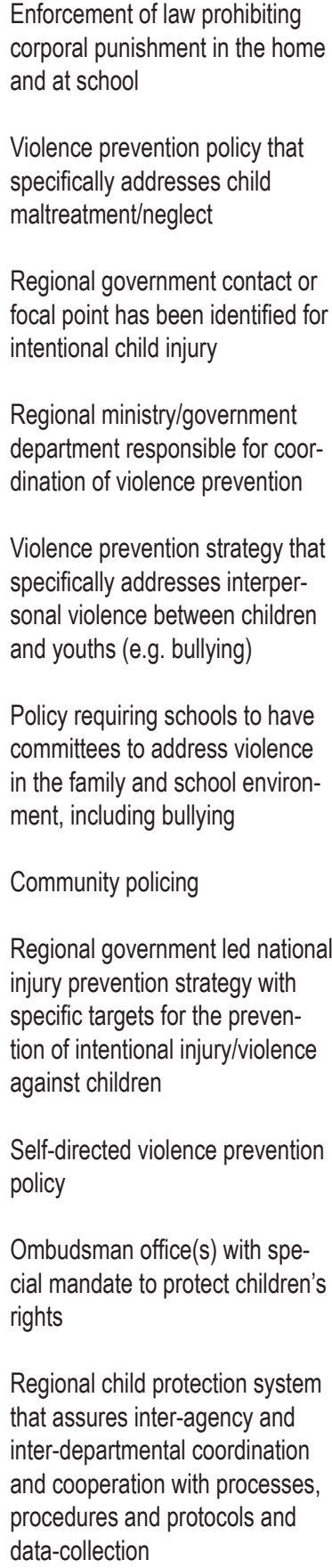 \\
\hline Event & & & & \\
\hline
\end{tabular}

Continued on next page 
Continued from previous page

\begin{tabular}{|c|c|c|c|c|}
\hline & 1 & 2 & 3 & 4 \\
\hline $\begin{array}{l}\text { Intentional } \\
\text { injury }\end{array}$ & $\begin{array}{l}\text { Policies and interventions } \\
\text { targeting the child }\end{array}$ & $\begin{array}{l}\text { Policies and interventions } \\
\text { targeting the agent (including } \\
\text { perpetrators of violence and } \\
\text { weapons) }\end{array}$ & $\begin{array}{c}\text { Policies and interventions } \\
\text { targeting the physical } \\
\text { environment }\end{array}$ & $\begin{array}{l}\text { Policies and interventions } \\
\text { targeting the social } \\
\text { environment }\end{array}$ \\
\hline Post-event & $\begin{array}{l}\text { Existence of services for victims } \\
\text { of physical abuse (therapeutic } \\
\text { day care, emphasis on improv- } \\
\text { ing cognitive and developmental } \\
\text { skills) } \\
\text { Policy that prescribes that all vic- } \\
\text { tims of child maltreatment receive } \\
\text { intervention/treatment } \\
\text { Existence of publicly funded child } \\
\text { helpline } \\
\text { Existence of services for children } \\
\text { who witness violence } \\
\text { Regional policy on support and } \\
\text { assistance for children who are } \\
\text { victims of violence/maltreatment } \\
\text { to ensure their access to justice } \\
\text { (e.g., child-friendly investigation, } \\
\text { interview and court proceedings } \\
\text { to avoid secondary or repeated } \\
\text { victimisation, child-sensitive } \\
\text { procedures) }\end{array}$ & $\begin{array}{l}\text { Existence of intensive family } \\
\text { preservation services }\end{array}$ & & 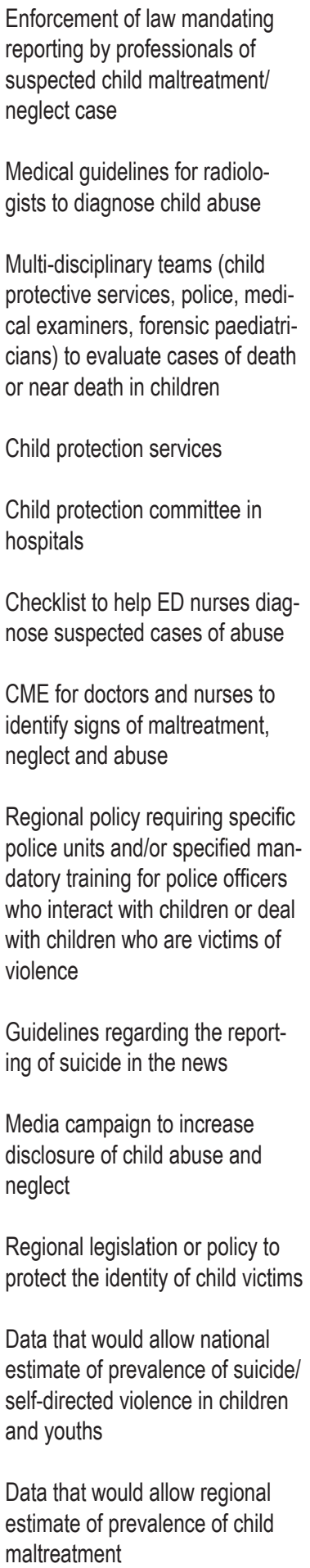 \\
\hline
\end{tabular}


Table 5. Fictitious example of a rapid appraisal for road safety

\begin{tabular}{|c|c|c|c|c|}
\hline Road & $\begin{array}{c}\text { Interventions } \\
\text { targeting the } \\
\text { host (child) }\end{array}$ & $\begin{array}{c}\text { Interventions } \\
\text { targeting } \\
\text { the "agent" } \\
\text { (vehicle/driver) }\end{array}$ & $\begin{array}{c}\text { Interventions } \\
\text { targeting } \\
\text { the physical } \\
\text { environment }\end{array}$ & $\begin{array}{c}\text { Interventions } \\
\text { targeting } \\
\text { the social } \\
\text { environment }\end{array}$ \\
\hline Pre-event & $67 \%$ & $75 \%$ & $100 \%$ & $43 \%$ \\
Event & $2 / 3$ & $3 / 4$ & $3 / 3$ & $3 / 7$ \\
\hline Post-event & $1 / 3$ & $\begin{array}{c}\text { zero } \\
\text { interventions } \\
\text { identified }\end{array}$ & $\begin{array}{c}\text { zero } \\
\text { interventions } \\
\text { identified }\end{array}$ & $50 \%$ \\
& $\begin{array}{c}\text { zero } \\
\text { interventions } \\
\text { identified }\end{array}$ & $\begin{array}{c}\text { zero } \\
\text { interventions } \\
\text { identified }\end{array}$ & $\begin{array}{c}\text { zero } \\
\text { interventions } \\
\text { identified }\end{array}$ & $1 / 6 \%$ \\
\hline
\end{tabular}

Conditional formatting is applied to the percentages assigning a shade of grey, with white representing $0 \%$ of interventions implemented and dark grey representing $100 \%$ of interventions implemented.

Leaend:

\begin{tabular}{|l|l|l|l|l|l|}
\hline $0 \%$ & $20 \%$ & $40 \%$ & $60 \%$ & $80 \%$ & $100 \%$ \\
\hline
\end{tabular}

\section{REFERENCES}

1. Sethi D, Raccoppi F, Baumgarten I, Vida P. Injuries and violence in Europe: why they matter and what can be done. Copenhagen: WHO Regional Office for Europe; 2006.

2. World Health Organization. WHO European Detailed Mortality Database (EDMD) [Internet]. Geneva WHO; 2016 [cited 2016 Nov 26]. Available from: http://data.euro.who.int/dmdb/.

3. Göpfert A, Sethi D, Rakovac I, Mitis F. Growing inequalities in child injury deaths in Europe. Eur J Public Health. 2015 Aug;25(4):660-2.

4. Green J, Edwards P. The limitations of targeting to address inequalities in health: a case study of road traffic injury prevention from the UK. Crit Public Health. 2008;18(2):175-87.

5. Mackay M, Vincenten J. Children's right to safety: inequity in child injury in Europe. Birmingham: European Child Safety Alliance; 2014.

6. Sengoelge M, Elling B, Laflamme L, Hasselberg M. Country-level economic disparity and child mortality related to housing and injuries: a study in 26 European countries. Inj Prev. 2013 Oct;19(5):311-5.

7. Simpson J, Fougere G, McGee R. A wicked problem: early childhood safety in the dynamic, interactive environment of home. Int J Environ Res Public Health. 2013 Apr 24;10(5):1647-64.

8. Towner E, Mytton J. Prevention of unintentional injuries in children. Paediatr Child Health. 2009;19(11):517-21.

9. Kickbusch I, Gleicher D. Governance for health in the 21 st century. Copenhagen: WHO Regional Office for Europe; 2012.

10. Racioppi F, Sethi D. Shaping comprehensive policies for injury prevention in Europe. Int J Inj Contr Saf Promot. 2009 Jun;16(2):65-71.

11. Edwards P, Roberts I, Green J, Lutchmun S. Deaths from injury in children and employment status in family: analysis of trends in class specific death rates. BMJ. 2006 Jul 15;333(7559):119.

12. Gissler M, Rahkonen O, Mortensen L, Arntzen A, Cnattingius S, Nybo Andersen AM, et al. Sex differences in child and adolescent mortality by parental education in the Nordic countries. J Epidemiol Community Health. 2012 Jan;66(1):57-63.

13. Edwards P, Green J, Lachowycz K, Grundy C, Roberts I. Serious injuries in children: variation by area deprivation and settlement type. Arch Dis Child. 2008 Jun;93(6):485-9.
14. Haynes R, Reading R, Gale S. Household and neighbourhood risks for injury to 5-14 year old children. Soc Sci Med. 2003 Aug;57(4):625-36.

15. Organization for Economic Co-operation and Development (OECD). Investing together: working effectively across levels of government. OECD Publishing; 2013.

16. Wilkinson J, Berghmans L, Imbert F, Ledésert B, Ochoa A; ISARE II project team. Health indicators in the European regions - ISARE II. Eur J Public Health. 2008 Apr;18(2):178-83.

17. MacKay JM, Vincenten JA. Leadership, infrastructure and capacity to support child injury prevention: can these concepts help explain differences in injury mortality rankings between 18 countries in Europe? Eur J Public Health. 2012 Feb;22(1):66-71.

18. Haddon W Jr. The changing approach to the epidemiology, prevention, and amelioration of trauma: the transition to approaches etiologically rather than descriptively based. 1968. Inj Prev. 1999 Sep;5(3):231-5.

19. Peiró R, Alvarez-Dardet C, Plasencia A, Borrell C, Colomer C, Moya C, et al. Rapid appraisal methodology for 'health for all' policy formulation analysis. Health Policy. 2002 Dec;62(3):309-28.

20. Benchmarking Regional Health Management II (Ben RHM II): final report [Internet]. Bielefeld: Institute of Public Health NRW; 2007 [cited 2016 Nov 26]. Available from: https://www.lzg.nrw.de/_media/pdf/ges_planen/ projekte/ben rhm-2 final report 2007.pdf.

21. MacKay M, Vincenten J, Brussoni M, Towner L. Child Safety Good Practice Guide: good investments in unintentional child injury prevention and safety promotion. Amsterdam: European Child Safety Alliance, EuroSafe; 2006.

22. MacKay M, Vincenten J, Brussoni M, Towner L. Child Safety Good Practice Guide: good investments in unintentional child injury prevention and safety promotion: addendum 2010. Amsterdam: European Child Safety Alliance, EuroSafe; 2010.

23. MacKay M, Vincenten J. Child Safety Report Card 2012: Europe Summary for 31 Countries. Birmingham: European Child Safety Alliance, Eurosafe; 2012.

24. MacKay M, Vincenten J. What are European countries doing to prevent intentional injury to children? National Action to Address Child Intentional Injury - 2014: Europe summary [Internet]. Birmingham: European Child Safety Alliance; 2014 [cited 2016 Nov 26]. Available from: http:// www.childsafetyeurope.org/archives/news/2014/info/ciir-report.pdf.

25. Peden M, Oyebite K, Ozanne-Smith J, Hyder A, Branche C, Fazlur Rahman AKM, et al. World Report on child injury prevention. Geneva: WHO; 2008.

26. Sethi D, Towner E, Vincenten J, Segui Gomez M, Racioppi F. European Report on Child Injury Prevention. Copenhagen: WHO Regional Office for Europe; 2008.

27. Krug E, Dahlberg L, Mercy J, Zwi A, Lozano R. World Report on Violence and Health. Geneva: WHO; 2002.

28. Brand H, Schröder P, Davies JK, Escamilla I, Hall C, Hickey K, et al. Reference frameworks for the health management of measles, breast cancer and diabetes (type II). Cent Eur J Public Health. 2006 Mar;14(1):39-45.

29. Marmot M. The Marmot Review Final Report: fair society, healthy lives. London (UK): University College London; 2010.

Received June 24, 2015 Accepted in revised form November 27, 2016 